\title{
BASELINE EXPERIMENTAL RESULTS ON THE EFFECT OF OIL TEMPERATURE ON SHROUDED MESHED SPUR GEAR WINDAGE POWER LOSS
}

\author{
Irebert R. Delgado \\ NASA Glenn Research Center \\ Cleveland, OH, USA
}

\author{
Michael J. Hurrell \\ HX5 Sierra LLC \\ NASA Glenn Research Center \\ Cleveland, $\mathrm{OH}, \mathrm{USA}$
}

\begin{abstract}
Rotorcraft gearbox efficiencies are reduced at increased surface speeds due to viscous and impingement drag on the gear teeth. This windage power loss can affect overall mission range, payload, and frequency of transmission maintenance. Experimental and analytical studies on shrouding for single gears have shown it to be potentially effective in mitigating windage power loss. Efficiency studies on unshrouded meshed gears have shown the effect of speed, oil viscosity, temperature, load, lubrication scheme, etc. on gear windage power loss. The open literature does not contain experimental test data on shrouded meshed spur gears. Gear windage power loss test results are presented on shrouded meshed spur gears at elevated oil inlet temperatures and constant oil pressure both with and without shrouding. Shroud effectiveness is compared at four oil inlet temperatures. The results are compared to the available literature and follow-up work is outlined.
\end{abstract}

\section{INTRODUCTION}

Rotorcraft gearboxes are critical in efficiently transferring power from the turboshaft jet engine to the main and tail rotors for a conventional helicopter. Efficiencies of 95 to 97 percent are common [1] as they are used in fixed wing aircraft such as geared turbofans and the VTOL (Vertical Take-Off and Landing) V-22 Osprey. With ever increasing fuel costs for air transportation, research is focused on demonstrating and maturing alternative and more efficient means of propulsion while minimizing aircraft weight [2]. This includes gearbox materials that improve overall life, alternative power transmission concepts that increase power density, reductions in gearbox form factor, as well as innovative lubrication methods that reduce the amount of required lubricant or means of cooling. One area of active research is in minimizing gearbox windage for rotorcraft transmissions. Gear windage power loss reduces the efficiency of the transmission due to drag on the gear teeth at high surface speeds. Not only is windage drag detrimental to gearbox efficiency, but the increased friction generates additional heating in the gearbox thereby placing more demand on cooling requirements. CFD analyses by Hill and others [3] show that this phenomenon is due to the air/oil environment impinging on the gear tooth face as well as on the sides of the gear. The resulting reduced transmission efficiency, negatively impacts rotorcraft performance [4].

Research has shown the potential for shrouding to reduce windage power loss for gears at high surface speeds. Dawson [5] studied the effect of clearance and percent shroud enclosure on a single spur gear in air and noted significant reductions in windage power loss using smooth circumferential shrouds with side plates at close clearances. Lord [6] also showed reductions in windage power loss for a shrouded single spur gear in air compared to the unshrouded case. In an air and oil environment for a single enclosed spur gear at $1 \mathrm{~mm}$ axial and radial clearance, he observed that power loss was higher than in an air only environment at the same clearance. By increasing the peripheral shrouding clearance, he observed a reduction in windage power loss but not to the levels shown for the same test in air only. The CFD analyses of Hill and others [3] compared well with experimental data taken from the NASA Glenn windage rig for a single shrouded spur gear. In contrast to Lord's [6] results, the smallest axial and radial shroud clearances minimized windage power loss.

A number of studies exist in the literature on unshrouded meshed spur gear windage power loss. Lord [6] provides power loss data on unshrouded meshed spur gears but not in the shrouded configuration. Ariura [7] presents torque loss data on unshrouded meshed spur gears with jet lubrication at various fluid viscosities. Experimental power loss data by Mizutani [8] for unshrouded meshed spur gears shows increasing values with increased loads and oil pressures. Petry-Johnson [9] shows the effect of oil viscosity of unshrouded meshed spur gears on spin 
losses which include churning losses, impingement losses, pocketing losses, and losses due to seals and bearings.

This work presents power loss experimental results for meshed spur gears at elevated oil temperatures both with and without shrouding at constant oil inlet pressure. The data is compared and contrasted with the available literature. Subsequent work to further study the effects of lubricant temperature and flow rate on shroud effectiveness is outlined.

\section{NOMENCLATURE}

$\begin{array}{ll}{ }^{\circ} \mathrm{F} & \text { degrees Fahrenheit } \\ \text { avg. } & \text { average } \\ \text { C1 } & \text { shroud configuration C1 } \\ \text { C36 } & \text { shroud configuration C36 } \\ \text { CFD } & \text { computational fluid dynamics } \\ \text { CS } & \text { clam-shell configuration } \\ \text { dc } & \text { direct current } \\ \text { deg. } & \text { degrees } \\ \text { ft. } & \text { feet } \\ \text { gpm } & \text { gallons per minute } \\ \text { hp } & \text { horsepower } \\ \text { Hz } & \text { Hertz } \\ \text { in-lb } & \text { inch-pounds } \\ \text { kW } & \text { kilowatt } \\ \text { IPIB } & \text { input inboard shaft bearing temperature } \\ \text { IPOB } & \text { input outboard shaft bearing temperature } \\ \text { min. } & \text { minute } \\ \text { mm } & \text { millimeters } \\ \text { mod. } & \text { module } \\ \text { N-m } & \text { newton meters } \\ \text { OPIB } & \text { output inboard shaft bearing temperature } \\ \text { OPOB } & \text { output outboard shaft bearing temperature } \\ \text { rpm } & \text { revolutions per minute } \\ \text { SAE } & \text { Society of Automotive Engineers } \\ \text { T100 } & 100^{\circ} \text { F oil inlet temperature } \\ \text { T125 } & 125^{\circ} \text { F oil inlet temperature } \\ \text { T160 } & 160^{\circ} \text { F oil inlet temperature } \\ \text { T180 } & 180^{\circ} \text { F oil inlet temperature } \\ \text { U } & \text { unshrouded configuration } \\ \text { VTOL } & \text { vertical take-off and landing } \\ & \end{array}$

\section{EXPERIMENT}

Windage power loss data were collected in NASA's gear windage research facility, Figure 1 . The input shaft of the test gearbox is connected to the $112 \mathrm{~kW}(150 \mathrm{hp})$ dc drive motor and 5.17:1 speed-up gearbox. An opposing torque can be applied on the test gearbox output shaft using the magnetic particle brake rated to $100 \mathrm{~N}-\mathrm{m}$ at $2865 \mathrm{rpm}$. Friction clutches (carbon on carbon friction wheels) located forward of the torquemeter and brake allow for disengagement of the test gearbox input and output shafts. This enables the test hardware (i.e. shafts, bearings, test gears) to coast down from a preset pitch-line velocity. Current tests were limited to approximately $28,000 \mathrm{ft} . / \mathrm{min}$.

Tests can be run with and without shrouding. Aluminum plates are used for the axial shrouds while sheet metal strips are used for radial shrouding, Figure 2. The shrouds are placed within a clam-shell housing, Figure 3 . The lower halves of both the drive- and driven-side clam-shell housing contain four oil drain holes each 0.75 -inch-wide by 3.5 inch long circumferentially. The shroud surface roughness is approximately 63 micro-inches. Six machined slots within the clam-shell housing allow for set clearances between the axial shroud wall and gear. The axial shroud walls, in turn, have 6 machined slots to vary the radial shroud position, Figures $2 \& 4$. In order to facilitate assembly of the rig, the clam-shell housing is composed of four pieces: 1) upper drive-side; 2) lower driveside; 3) upper driven-side; 4) lower driven-side. The entire assembly is mounted within the test gearbox enclosing the test gears, Figure 3. Although not specifically designed to be used as a shroud, the clam-shell housing was tested as an intermediate shroud condition to assess windage power loss with additional drain holes and grooves as shown in Figure 2 and Figure 3.

The gear fling-off temperature for all configurations was measured at the 1 o'clock position on the drive-side pinion. Lubrication was directed into-mesh, nominally at $0.9 \mathrm{gpm}$ at constant pressure. The lubricant used was Royco 555, a synthetic oil used specifically for gas turbine engines and helicopter transmissions [10]. The shaft bearing temperatures were monitored throughout testing. Shaft bearing locations are shown in Figure 5.

All tests were run with a 10 in-lb. counter-torque to prevent gear tooth disengagement during rotation. The spur pinion and gear specifications are given in Table 1. Meshed spur gear tests were run in an unshrouded and shrouded configuration at four oil inlet temperatures: $100^{\circ} \mathrm{F}, 125^{\circ} \mathrm{F}, 160^{\circ} \mathrm{F}$, and $180^{\circ} \mathrm{F}$. The oil inlet temperature was measured at a point in the stainless steel oil inlet supply approximately 5 feet prior to entering the test gearbox. The oil out, or exit temperature, was located in the gearbox drain line just outside of the gearbox underside. Two unshrouded configurations were tested: $U$ and CS. The U configuration is simply the two meshed spur gears installed in the gearbox. The CS configuration is the $\mathrm{U}$ configuration with the clam-shell housing installed. The two shrouded configurations, C36 and $\mathrm{C} 1$, are at the maximum axial/radial and minimum axial/radial clearances, respectively. Table 2 provides the clearances for the unshrouded and shrouded configurations.

The meshed spur gears were rotated to $10,000 \mathrm{rpm}$ in 2000 rpm increments. The speed was changed every 100 seconds with approximately 20 seconds used to transition to the next speed increment and 80 seconds to hold at speed. After holding at the $10,000 \mathrm{rpm}$ condition the drive motor and dynamometer are simultaneously disengaged allowing the test gears, input shaft, and output shaft to coast-down. This process was repeated for a total of three cycles. An example ramp-up and 
wind-down cycle is shown in Figure 6. Data was recorded in LabView at $3 \mathrm{~Hz}$, capture rate.

The windage power loss for the meshed spur gears is determined by first calculating the angular acceleration derived from the velocity versus time measurements captured during disengagement of the system (i.e. meshed spur gears, shaft, and bearings). The system torque is given by the product of the angular acceleration and the equivalent inertia of the meshed spur gears. The system windage power loss is the product of the torque and shaft speed. Subtracting the tare power loss (i.e. shaft and bearings only) from the total system power loss determines the windage power loss due to the meshed spur gears. Further details are provided in Annex A and shown in [11].

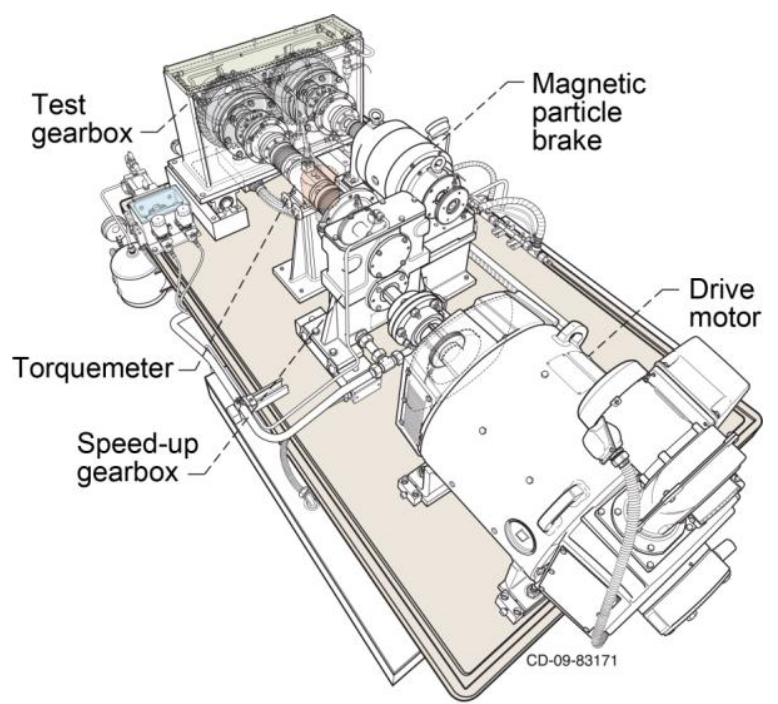

Figure 1 Schematic of Gear Windage Test Facility.

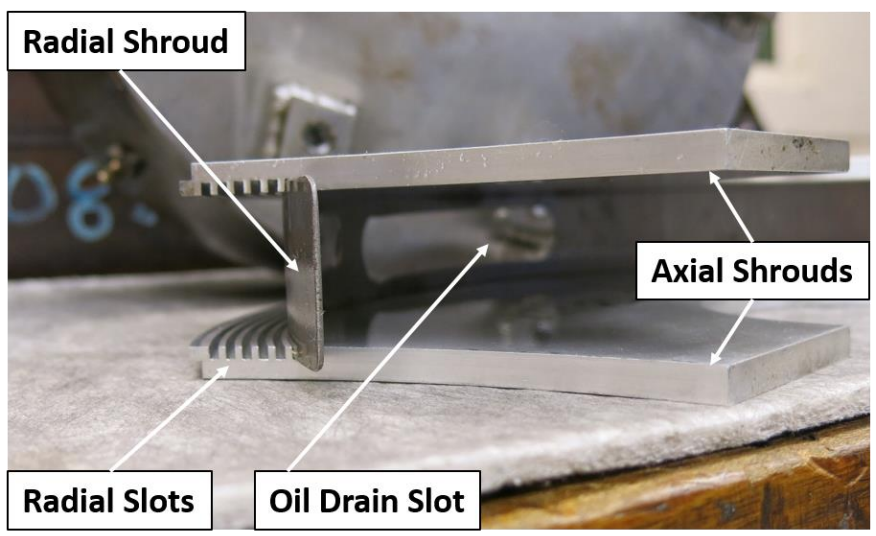

Figure 2 Configuration of radial and axial shrouding.

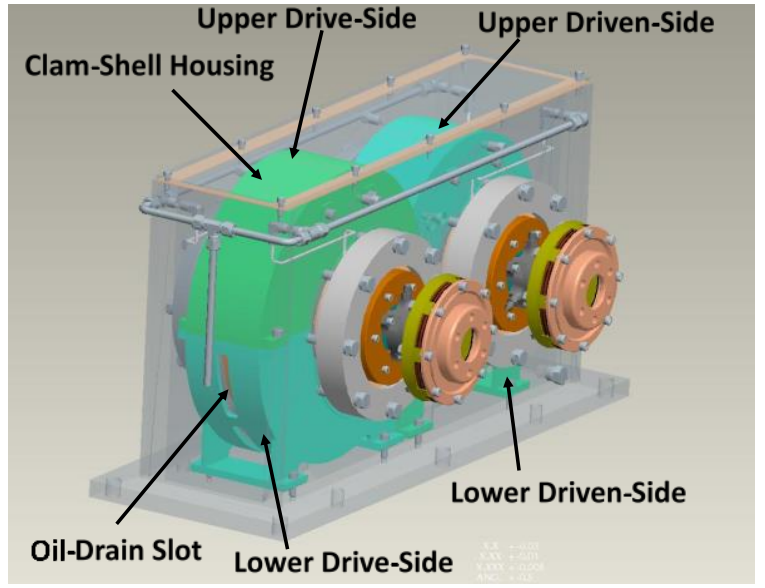

Figure 3 Test gearbox showing clam-shell (CS) enclosure for shrouding within NASA Gearbox.

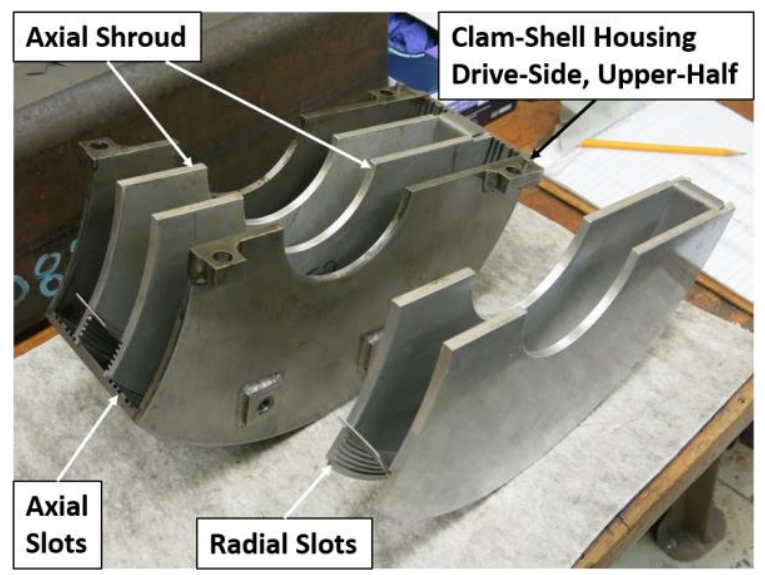

Figure 4 Configuration of axial and radial shrouding using machined slots. 


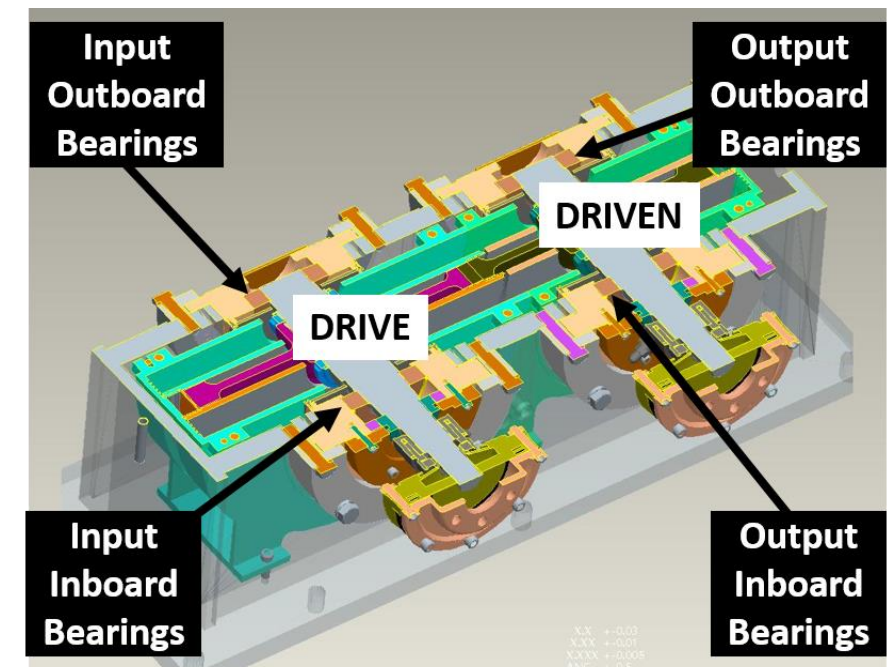

Figure 5 Drive and driven gear shaft bearing temperature locations.

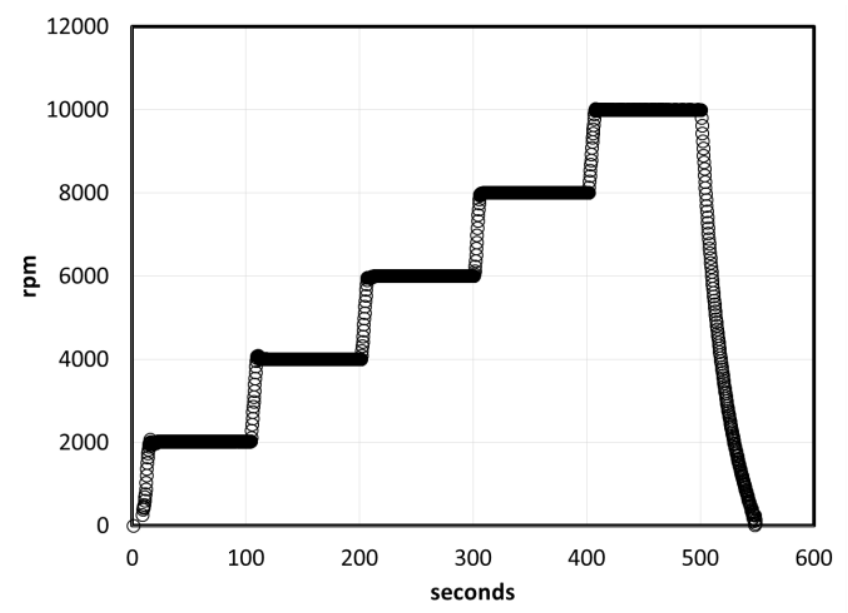

Figure 6 Example windage test ramp-up and wind-down cycle.

Table 1 Pinion (drive-side) and gear (driven-side) specifications.

\begin{tabular}{|l|c|c|}
\hline number of teeth & Drive-side & Driven-side \\
\hline pitch/mod.,1/in. (mm) & \multicolumn{2}{|c|}{4 (6.35) } \\
\hline face width in. (mm) & $1.12(28.4)$ & $1.12(28.4)$ \\
\hline pitch dia., in. (mm) & $11.0(279.4)$ & $13.0(330.2)$ \\
\hline pressure angle, deg. & \multicolumn{2}{|c|}{25} \\
\hline outside dia., in. (mm) & 11.49 & 13.49 \\
\hline
\end{tabular}

material
Table 2 Shroud configuration clearances.

\begin{tabular}{|c|c|c|c|}
\hline $\begin{array}{c}\text { Shroud } \\
\text { Configuration }\end{array}$ & $\begin{array}{c}\text { Axial } \\
\text { Clearance }\end{array}$ & \multicolumn{2}{|c|}{$\begin{array}{c}\text { Radial } \\
\text { Clearance }\end{array}$} \\
\hline $\begin{array}{c}\text { Per side } \\
\text { [inches] }\end{array}$ & $\begin{array}{c}\text { Drive- } \\
\text { side } \\
\text { [inches] }\end{array}$ & $\begin{array}{c}\text { Driven- } \\
\text { side } \\
\text { [inches] }\end{array}$ \\
\hline $\begin{array}{c}\text { Unshrouded } \\
\text { w/o clam-shell } \\
\text { housing } \\
\text { (CS) }\end{array}$ & 2.25 & 2.5 & 1.0 \\
\hline $\begin{array}{c}\text { Unshrouded } \\
\text { w/clam-shell } \\
\text { housing }\end{array}$ & 1.5 & 0.82 & 0.82 \\
\hline $\begin{array}{c}\text { (C36) } \\
\text { Shrouded }\end{array}$ & 1.17 & 0.66 & 0.66 \\
\hline $\begin{array}{c}\text { (C1) } \\
\text { Shrouded }\end{array}$ & 0.039 & 0.039 & 0.039 \\
\hline \begin{tabular}{c} 
[ingen \\
\hline
\end{tabular} & & & \\
\hline
\end{tabular}

\section{RESULTS}

Windage power loss data is presented for the unshrouded (U) configuration without the clam-shell housing installed and the shrouded $\mathrm{C} 1$ configuration at $100^{\circ} \mathrm{F}, 125^{\circ} \mathrm{F}, 160^{\circ} \mathrm{F}$, and $180^{\circ} \mathrm{F}$ oil inlet temperatures. Figure 7 and Figure 8 show these data sets. The CS configuration test results are nearly identical to the $\mathrm{U}$ configuration data and the $\mathrm{C} 36$ shrouded configuration test results are nearly identical with those of the $\mathrm{C} 1$ shrouded configuration. The average oil inlet temperatures and instantaneous gear fling-off temperatures during the cycle 3 coast-down for each of the 4 target oil inlet temperatures are given in Table 3. Although not shown, the power loss for each configuration (U, CS, C36, and C1) was found to be unaffected by changes to the oil inlet temperature $\left(100^{\circ} \mathrm{F}, 125^{\circ} \mathrm{F}, 160^{\circ} \mathrm{F}\right.$, and $180^{\circ} \mathrm{F}$ ).

Figure 9 and Figure 10 show windage power loss data at nominal oil inlet temperatures of $100^{\circ} \mathrm{F}$ and $180^{\circ} \mathrm{F}$ at each of the four shroud configurations: $\mathrm{U}, \mathrm{CS}, \mathrm{C} 36$, and $\mathrm{C} 1$. Test data at $125^{\circ} \mathrm{F}$ and $160^{\circ} \mathrm{F}$ nominal oil inlet temperatures is similar to those in Figure 9 and Figure 10 . The C36 and C1 configurations are slightly lower in power loss than the $\mathrm{U}$ and CS configurations. This is evident when comparing windage power loss values for the 4 configurations $15,000 \mathrm{ft} . / \mathrm{min}$.

For the four configurations tested Table 5 shows average oil inlet, oil exit, gear oil flow and bearing oil flow at each of the four test temperatures. Each oil temperature or bearing flow value is an average of four tests at a specific 'nominal oil inlet temperature'. The four tests are the 4 shroud conditions: U, CS, $\mathrm{C} 36$, and $\mathrm{C} 1$. Each of the 4 values are an average of 100 data 
points taken during the wind-down cycle where windage data is being acquired. For example, in Table 5, the 0.85 GPM avg. gear oil flow corresponding to the 'amb' nominal oil inlet temperature is an average of the gear oil flow from the 4 shroud conditions: U, CS, C36, and C1. They are 0.73 GPM, 0.90 GPM, 0.87 GPM, and 0.91 GPM, respectively. The value of $0.73 \mathrm{GPM}$ is an average of 100 data points taken specifically during the wind-down portion of the unshrouded (U) configuration at ambient test temperature.

At constant oil pressure, the gear into-mesh and bearing oil flow were observed to increase with test oil inlet temperature, Table 5. Gear oil flow increased from $0.85 \mathrm{gpm}$ to $1.50 \mathrm{gpm}$ while the bearing oil flow increased from $0.18 \mathrm{gpm}$ to 0.27 gpm. The average oil inlet temperature increased from $103^{\circ} \mathrm{F}$ to $189^{\circ} \mathrm{F}$ and the average oil out temperature increased from $152^{\circ} \mathrm{F}$ to $211^{\circ} \mathrm{F}$.

Shaft bearing temperatures during cycle 3 coast-down are given in Figure 11 and Figure 12 for the unshrouded (U) and the C1 shroud configuration (e.g. 0.039 inch axial and radial clearance), respectively. Within each graph (configuration), four families of bearing temperatures (e.g. IPIB, IPOB, OPIB, OPOB) are plotted corresponding to the four nominal oil inlet temperatures (e.g. $100^{\circ} \mathrm{F}, 125^{\circ} \mathrm{F}, 160^{\circ} \mathrm{F}, 180^{\circ} \mathrm{F}$ ). Table 4 provides the legend for the data points in Figure 11 and Figure 12. Overall, the change in bearing temperature during winddown varies from $-13^{\circ} \mathrm{F}$ to $+2^{\circ} \mathrm{F}$. Also, bearing temperatures are higher with increasing oil inlet temperature. With the exception of the $160^{\circ} \mathrm{F}$ and $180^{\circ} \mathrm{F}$ unshrouded (U) datasets (Figure 11) the highest bearing temperature at the start of deceleration is at the outboard inboard bearing (OPIB). The unshrouded (U) configuration, Figure 11, shows bearing temperature standard deviations of no more than 3 to $6^{\circ} \mathrm{F}$ for each oil inlet temperature as contrasted to the bearing temperature standard deviations of the $\mathrm{CS}\left(10\right.$ to $\left.12^{\circ} \mathrm{F}\right), \mathrm{C} 36$ (16 to $\left.18^{\circ} \mathrm{F}\right)$ and $\mathrm{C} 1$ (17 to $\left.18^{\circ} \mathrm{F}\right)$ configurations.

Finally, the gearbox surface was noticeably cooler for the C1 configuration versus the unshrouded (U) configuration. Figure 13 shows the increase in gear fling-off temperature over the 30 minute, 3 cycle test for each of the four configurations. The time increments labeled ' 1 ', ' 2 ', and ' 3 ' denote the approximately 40 second period where wind-down occurs. The 500 seconds prior to disengaging the meshed gears from the motor and dynamometer denote $2000 \mathrm{rpm}$ increments up to $10,000 \mathrm{rpm}$. With each successive cycle the gear fling-off temperature is observed to increase slightly to a higher maximum temperature at the start of wind-down than the previous cycle. The $\mathrm{C} 1$ configuration with an axial and radial clearance of 0.039 inches is observed to have a gear fling-off temperature $40-50^{\circ} \mathrm{F}$ higher than the other three configurations. Note that the gear fling-off thermocouple in the $\mathrm{C} 1$ configuration is approximately 0.5 inches radially closer to the pinion than in the CS or C36 configuration. The smaller heat capacity of the air/oil mixture in the shroud/gear space for the C1 shroud configuration and the closer proximity of the thermocouple to the heat source may be contributing factors resulting in the higher fling-off temperatures.

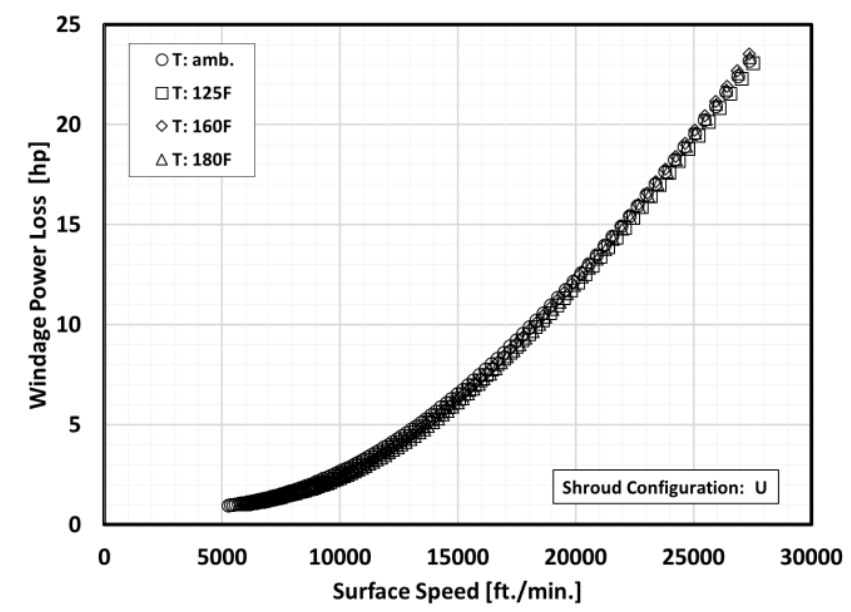

Figure 7 Unshrouded (U) windage power loss test results for meshed spur gears at four oil inlet temperatures.

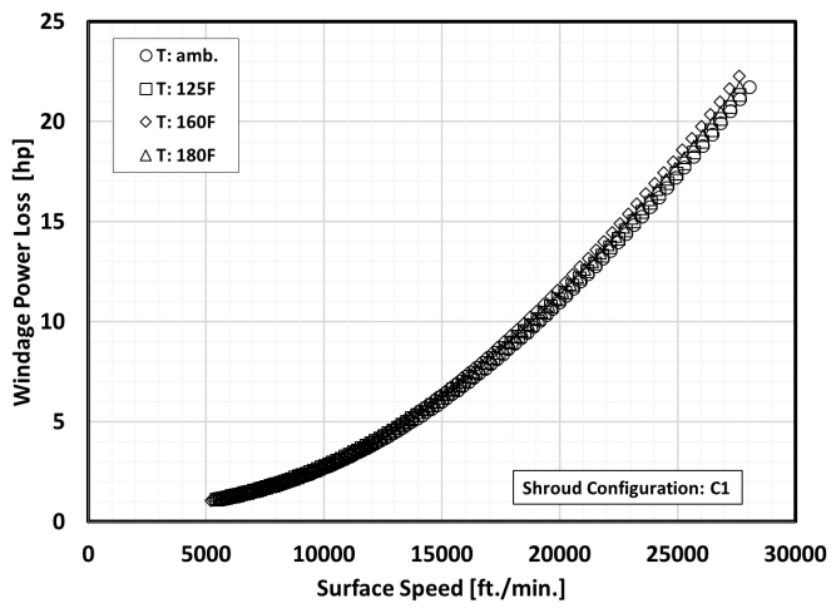

Figure $8 \mathrm{C} 1$ shroud configuration power loss test results for meshed spur gears at 4 oil inlet temperatures. 


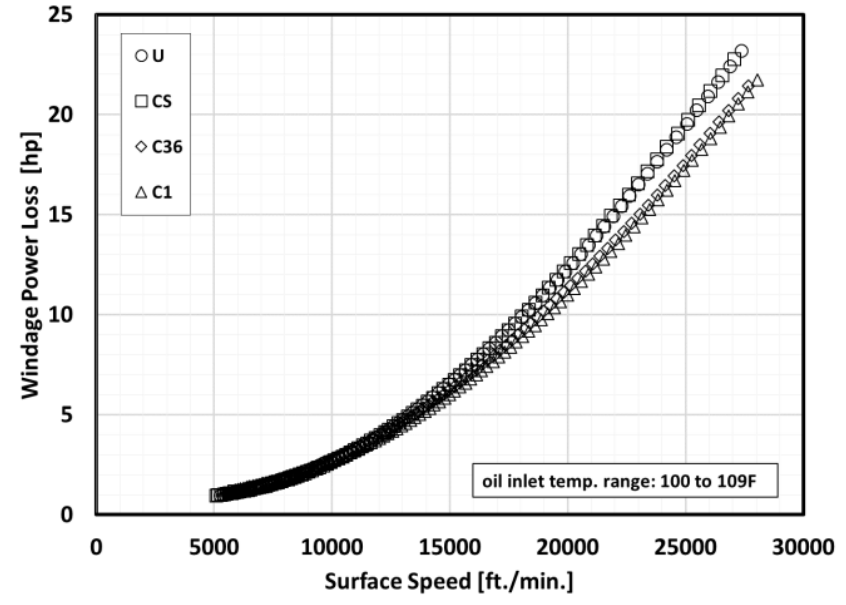

Figure 9 Comparison of windage power loss at $100^{\circ} \mathrm{F}$ nominal oil inlet temperature for $\mathrm{U}, \mathrm{CS}, \mathrm{C36}$, and $\mathrm{C1}$ shroud configurations.

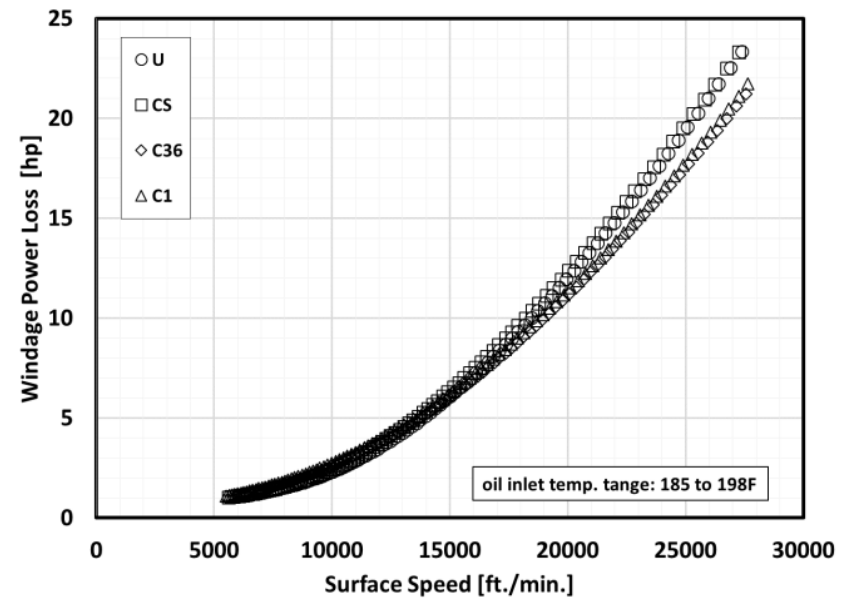

Figure 10 Comparison of windage power loss at $180^{\circ} \mathrm{F}$ nominal oil inlet temperature for $\mathrm{U}, \mathrm{CS}, \mathrm{C36}$, and $\mathrm{C1}$ shroud configurations.
Table 3 Test average oil inlet and instantaneous gear flingoff temperatures.

\begin{tabular}{|c|c|c|c|c|c|}
\hline Configuration & U & CS & C36 & C1 \\
\hline $\begin{array}{c}\text { Oil inlet } \\
\text { temp. [ }{ }^{\circ} \text { F] }\end{array}$ & \multicolumn{3}{|c|}{ Average Oil inlet temp. [ ${ }^{\circ}$ F] } \\
\hline 100 & 99.8 & 102.3 & 101.5 & 109.3 \\
\hline 125 & 130.8 & 128.8 & 127.9 & 127.8 \\
\hline 160 & 164.2 & 166.4 & 166.3 & 166.4 \\
\hline 180 & 186.9 & 186.1 & 184.8 & 198.1 \\
\hline $\begin{array}{c}\text { Oil inlet } \\
\left.\text { temp. [ }{ }^{\circ} \mathrm{F}\right]\end{array}$ & Instantaneous Gear fling-off temp. [ $\left.{ }^{\circ} \mathrm{F}\right]$ \\
\hline $\mathbf{1 0 0}$ & 195 & 198 & 192 & 222 \\
\hline $\mathbf{1 2 5}$ & 215 & 211 & 210 & 238 \\
\hline $\mathbf{1 6 0}$ & 231 & 230 & 232 & 263 \\
\hline $\mathbf{1 8 0}$ & 246 & 243 & 245 & 286 \\
\hline
\end{tabular}

Table 4 Legend for Figure 11 and Figure 12. Shaft bearing locations are shown in Figure 5. See Nomenclature for description of acronyms below.

\begin{tabular}{|c|c|c|c|c|c|}
\hline $\begin{array}{l}\text { Inp } \\
\text { Inbo }\end{array}$ & & $\begin{array}{l}\text { In } \\
\text { Out }\end{array}$ & & & Ou \\
\hline T100:IPIB & $\square$ & T100:IPOB & $\diamond$ & IB & $\triangle T$ \\
\hline T12 & & T1 & $\gamma$ & B & $\mathrm{T} 1$ \\
\hline T160:IPIB & & & 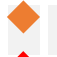 & & $\mathrm{T} 1$ \\
\hline Т180 & & T180:IPOB & & T180:OPIB & Т180:ОРОВ \\
\hline
\end{tabular}


Table 5 Average gear mesh and bearing oil flows at oil inlet test temperatures, combining data from $\mathrm{U}, \mathrm{CS}, \mathrm{C36}$, and $\mathrm{C1}$ configurations.

\begin{tabular}{|c|c|c|c|c|}
\hline $\begin{array}{c}\text { nominal } \\
\text { oil inlet } \\
\text { temp. } \\
\text { [ }{ }^{\circ} \text { [] }\end{array}$ & $\begin{array}{c}\text { avg. } \\
\text { oil inlet } \\
\text { temp. } \\
\text { [ }{ }^{\circ} \text { F] }\end{array}$ & $\begin{array}{c}\text { avg. } \\
\text { oil out } \\
\text { temp. } \\
\text { [ }{ }^{\circ} \text { F] }\end{array}$ & $\begin{array}{c}\text { avg. } \\
\text { gear } \\
\text { oil-flow } \\
\text { [gpm] }\end{array}$ & $\begin{array}{c}\text { avg. } \\
\text { bearing } \\
\text { oil-flow } \\
\text { [gpm] }\end{array}$ \\
\hline amb. & 103 & 152 & 0.85 & 0.18 \\
\hline $\mathbf{1 2 5}$ & 129 & 169 & 1.10 & 0.21 \\
\hline $\mathbf{1 6 0}$ & 166 & 191 & 1.36 & 0.24 \\
\hline $\mathbf{1 8 0}$ & 189 & 211 & 1.50 & 0.27 \\
\hline
\end{tabular}

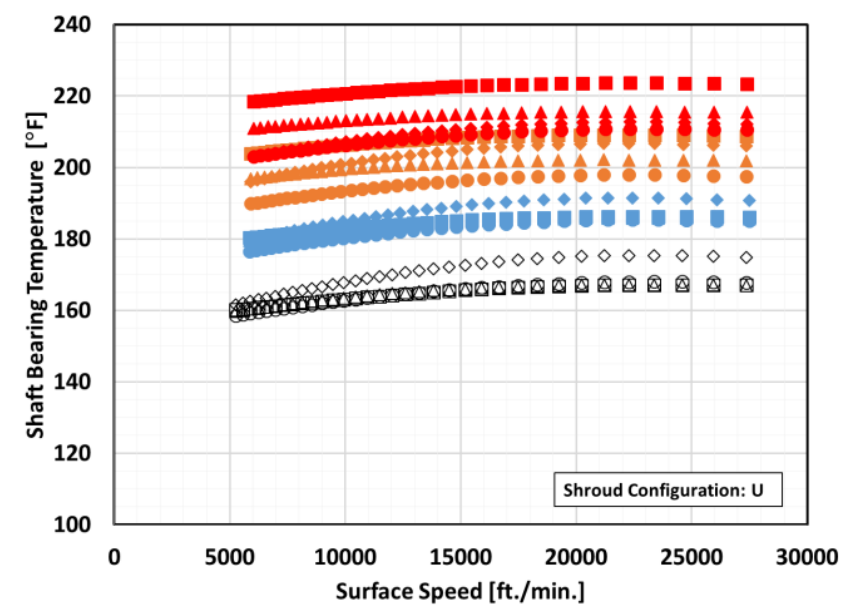

Figure 11 Shaft bearing temperatures during deceleration for unshrouded (U) meshed spur gears at 4 oil inlet temperatures. See Table 4 for Legend.

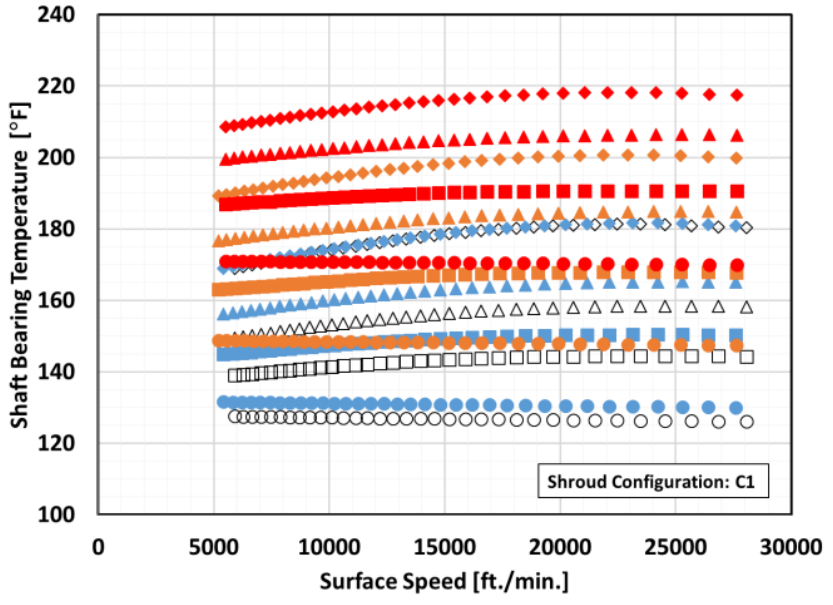

Figure 12 Shaft bearing temperatures during deceleration for $\mathrm{C} 1$ configured meshed spur gears at 4 oil inlet temperatures. See Table 4 for Legend.

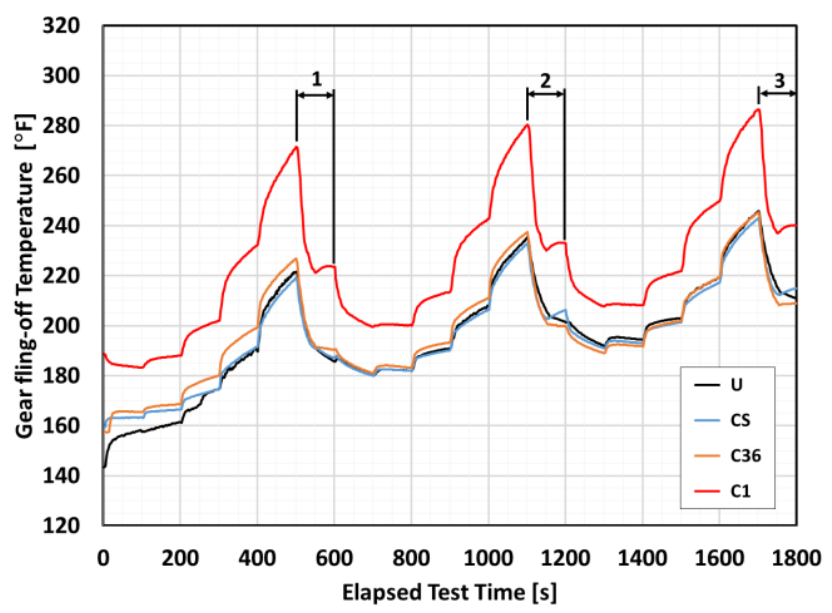

Figure 13 Time-trace of gear fling-off temperature for the $\mathrm{U}, \mathrm{CS}, \mathrm{C36}$, and $\mathrm{C} 1$ configurations at $180^{\circ} \mathrm{F}$ oil inlet temperature.

\section{DISCUSSION}

Researchers have shown decreasing windage power loss levels with increasing oil temperature or decreased viscosity. Ariura [7] shows a decrease in windage power loss for unshrouded meshed spur gears at lower viscosities (i.e. higher oil temperature) at surface speeds of up to $12,000 \mathrm{ft} . / \mathrm{min}$.. Lord [6] shows a small decrease in windage power loss with increased oil temperature 30 to $40^{\circ} \mathrm{C}\left(86\right.$ to $\left.104^{\circ} \mathrm{F}\right)$ for a single shrouded spur gear. Finally, Seetharaman shows reductions in windage power loss for meshed spur gears in air at 4 temperatures [12]. Given the data from the literature, the expectation was that power loss results, Figure 7 and Figure 8, 
would show a decreasing trend with increasing oil inlet temperature. However, Lord [6] also shows an increase in windage power loss with increasing oil flow for meshed spur gears. For the NASA tests at constant pressure, the flow was observed to increase with increasing temperature, Table 5. The decrease in windage power loss due to the decreasing oil viscosity is likely offset by the increase in oil flow rate with increasing temperature. It is unknown why the windage power loss values are nearly identical for the four oil inlet temperatures, Figure 7 and Figure 8. The drop in windage power loss comparing the $\mathrm{U}$ and $\mathrm{CS}$ configurations with the $\mathrm{C} 36$ and $\mathrm{C} 1$ shroud configurations is due to the use of shrouding. Details are given by the authors in [11]. Further work is needed to understand why the C36 and C1 shroud configurations are nearly identical despite the reduction in axial and radial clearance. It is also noted that the oil inlet temperatures $\left(101^{\circ} \mathrm{F}\right.$ vs. $\left.109^{\circ} \mathrm{F}\right)$, gear mesh oil flows $(0.91 \mathrm{gpm}$ vs. $0.86 \mathrm{gpm})$ and bearing oil flows (0.19 gpm vs. $0.18 \mathrm{gpm})$ are nearly identical for the $\mathrm{C} 36$ and $\mathrm{C} 1$ shroud configurations, respectively.

Given the results above, shroud effectiveness may be reduced if oil temperatures and oil flows are not considered. Rotorcraft gearbox performance dictates the lubrication and cooling requirements for the gears and bearings involved in the drive system. The components are designed to operate at a specific range of temperature, speed, and torque. These requirements dictate the sizing of the oil jets and pumps that provide the required lubrication and cooling [13-16]. During actual flight the gearbox will operate over a range of temperature and speed. Thus, oil flows may change accordingly.

As noted above, the gearbox was noticeably cooler for the $\mathrm{C} 1$ shroud configuration than the $\mathrm{U}$ configuration. Referring to Figure 3, for the $\mathrm{C} 1$ shroud configuration, the clam-shell housing and requisite $\mathrm{C} 1$ shrouding appear to limit heat transfer to the surrounding gearbox structure. Lubricating oil is piped into the gear mesh from the top of the $\mathrm{C} 1$ shrouding. It is allowed to drain out of the shroud and clam shell housing through drain slots located at the 6 o'clock position. In the unshrouded (U) configuration, jetted oil impacting the spur gears into-mesh is flung around the gears, coating the interior walls of the gearbox.

The cooler gearbox touch temperature for the $\mathrm{C} 1$ shroud configuration is consistent with the smaller bearing temperature variation for the unshrouded (U) configuration, Figure 11, compared to the other three configurations (CS, C36, C1) as given in the Results section. For example, at the $100^{\circ} \mathrm{F}$ oil inlet temperature condition, bearing temperature ranges for the $\mathrm{U}$ configuration were $160-175^{\circ} \mathrm{F}$ compared to $125-180^{\circ} \mathrm{F}$ for the $\mathrm{C} 1$ configuration. At the $180^{\circ} \mathrm{F}$ oil inlet temperature the range in bearing temperatures for the $\mathrm{U}$ configuration was approximately $200-225^{\circ} \mathrm{F}$ compared to $170-220^{\circ} \mathrm{F}$ for the $\mathrm{C} 1$ configuration. The trace of gear fling-off temperature at a nominal oil inlet temperature of $180^{\circ} \mathrm{F}$ in Figure 13 is also indicative of the increased thermal energy or heat in the system. Recall that the gear fling-off temperature is measured just inside the radial shroud. Additional temperature measurements both inside and outside the shrouding would shed light on the extent and range of fluctuations in and around the gear, mesh area, and surrounding gearbox. In general, shrouding could potentially be configured to locally control and enhance thermal energy transport within the gearbox just outside the vicinity of the meshed gears.

Oil temperature and viscosity are currently accounted for in gear mesh loss calculations as noted in Annex A and detailed in [11]. Consider that the average oil out temperature, Table 5, is approximately 20 to $50^{\circ} \mathrm{F}$ higher than the average oil inlet temperature. Consider also that the gear fling-off temperatures are 60 to $113^{\circ} \mathrm{F}$ higher than their respective oil inlet temperature. Further analysis may necessitate a revised oil temperature that would better approximate the 'average' oil temperature for a particular test. Future tests using thermocouple readings in close proximity at the periphery of the meshed spur gears would account for the likely hottest oil temperature reading just out-of-mesh of the spur gears.

\section{CONCLUSIONS}

Windage power loss test data is presented for meshed spur gears at four oil inlet temperatures: $100^{\circ} \mathrm{F}, 125^{\circ} \mathrm{F}, 160^{\circ} \mathrm{F}$, and $180^{\circ} \mathrm{F}$. Four shroud configurations were tested: unshrouded without the clam-shell housing installed, (CS) unshrouded with the clam-shell housing installed, shroud configuration $\mathrm{C} 36$, and shroud configuration $\mathrm{C} 1$. At constant oil pressure, the oil flow to the gear mesh and bearings was observed to increase with temperature.

1. The resulting windage power loss data were identical for the $\mathrm{U}$ and $\mathrm{CS}$ configurations.

2. The windage power loss associated with the $\mathrm{C} 36$ and $\mathrm{C} 1$ configurations were identical to each other but lower than the $\mathrm{U}$ and $\mathrm{CS}$ configurations.

3. Shroud effectiveness may be reduced if oil temperatures and oil flows are not considered.

4. Analysis of the gearbox bearing temperatures for different shroud configurations found that shrouding appears to limit conductive and convective heat transfer to the surrounding structure. This could potentially be used to limit localized heating to the vicinity of the rotating gears.

5. Estimates of power savings for optimal rotorcraft shrouding should always be stated, or qualified, for a given temperature and lube flow rate. The study presented herein highlights the importance of these parameters on the effectiveness of a given shroud configuration in reducing gearbox windage losses. 


\section{ACKNOWLEDGMENTS}

The authors acknowledge the support of the NASA Revolutionary Vertical Lift Technology Project and also to Sigurds Lauge (HX5 Sierra LLC) for technical test support.

\section{REFERENCES}

[1] Weden, Gilbert J., and John J. Coy. "Summary of drive-train component technology in helicopters." (1984).

[2] http://www.hq.nasa.gov/office/aero/pdf/armd-strategicimplementation-plan.pdf

[3] Hill, Matthew J., et al. "CFD analysis of gear windage losses: Validation and parametric aerodynamic studies." Journal of Fluids Engineering 133.3 (2011): 031103.

[4]https://www.faa.gov/regulations_policies/handbooks_manual s/aviation/helicopter_flying_handbook/

[5] Dawson, P. H. "Windage loss in larger high-speed gears." Proceedings of the Institution of Mechanical Engineers, Part A: Power and Process Engineering 198.1 (1984): 51-59.

[6] Lord, Andrew Alan. Experimental investigation of geometric and oil flow effects on gear windage and meshing losses. Diss. University of Wales Swansea, 1998.

[7] Ariura, Yasutsune, et al. "The lubricant churning loss in spur gear systems." Bulletin of JSME 16.95 (1973): 881-892.

[8] Mizutani, Hachiro, Yuuichi Isikawa, and Dennis P. Townsend. Effects of lubrication on the performance of high speed spur gears. No. NASA-TM-101969. NATIONAL AERONAUTICS AND SPACE ADMINISTRATION CLEVELAND OH LEWIS RESEARCH CENTER, 1989.

[9] Petry-Johnson, Travis T., et al. "An experimental investigation of spur gear efficiency." Journal of Mechanical Design 130.6 (2008): 062601.

[10] http://qclubricants.com/msds/PDS/Royco555.pdf [11] Delgado, Irebert, and Michael Hurrell. "Experimental Investigation of Shrouding on Meshed Spur Gear Windage Power Loss.” American Helicopter Society. (2017)

[12] Seetharaman, Satya, and Ahmet Kahraman. "A windage power loss model for spur gear pairs." Tribology Transactions 53.4 (2010): 473-484.

[13] Henry, Zachary S. Bell Helicopter Advanced Rotorcraft Transmission (ART) Program. No. NASA-E-9708. BELL HELICOPTER CO FORT WORTH TX ELECTRONICS DEPT, 1995.

[14] Lenski Jr, Joseph W. Advanced Rotorcraft Transmission Program (ART). No. D210-12966-1. BOEING DEFENSE AND SPACE GROUP PHILADELPHIA PA HELICOPTERS DIV, 1995.

[15] HEATH, GREGORY F, and ROBERT BOSSLER. "Advanced Rotorcraft Transmission (ART) program (Final Report)." (1993).

[16] Kish, Jules G. "Sikorsky Aircraft Advanced Rotorcraft Transmission (ART) Program." (1993). 


\section{ANNEX A}

\section{GEAR WINDAGE POWER LOSS CALCULATION}

The total power loss consists of gear mesh losses, rig driveline losses, and windage losses. Considering the light loading of the gear set during the tests reported herein, the gear mesh losses are minimal. Gear mesh losses are conservatively calculated to be $0.15 \mathrm{hp}$ at $10 \mathrm{in}-\mathrm{lb}$ torque based on analyses by Anderson et.al. [A1]. The rig driveline losses, or tare losses consist of power losses associated with the spinning drive shaft, driven shaft, and support bearings. These losses were determined by performing coast down tests without the test gears installed. The tare windage power loss for the drive shaft and bearing assembly was experimentally determined at each test temperature. The driven shaft and bearing assembly tare windage power loss were assumed to be the same since both shafts are nearly identical with the exception of the gear spline diametral pitch.

Similar to Dawson [A2], power loss due to windage was calculated, in part, by plotting the angular velocity versus time curve during free deceleration and measuring the slope or instantaneous angular acceleration at various points on that curve. Torque is given by the product of the angular acceleration and the moment of inertia. An equivalent moment of inertia, Jeq, for the meshed gear system is given by Equation A1. The power (or windage power loss) of the meshed gear system is calculated from the product of the torque and the shaft speed. Finally, the windage power loss due the gears alone is given by subtracting the tare power losses and gear mesh losses from the power loss of the meshed gear system.

$$
\begin{gathered}
J_{e q}=J_{1}+J_{2}\left(\frac{N_{1}}{N_{2}}\right)^{2} \quad \text { [A3] Equation A1 } \\
\text { where } \quad \mathrm{J}_{1}=\text { moment of inertia of the pinion } \\
\mathrm{J}_{2}=\text { moment of inertia of the gear } \\
\mathrm{N}_{1}=\text { number of pinion teeth } \\
\mathrm{N}_{2}=\text { number of gear teeth }
\end{gathered}
$$

Component inertias were measured using the curved rail method outlined by Genta et.al. [A3]. Figure A1 shows the experimental set-up for the curved rail procedure. The test shaft assemblies, drive and driven, were assembled with and without the test gears. The inertias measured using the test shaft assemblies without the test gears are used in calculating the rig driveline losses. The inertias measured using the test shaft assemblies with the test gears are used in determining the gear windage losses.

$$
J=m r^{2}\left[\frac{g T^{2}}{4 \pi(R-r)}-1\right]
$$

where $\quad I=$ moment of inertia of the assembly $m=$ total mass of the assembly $r=$ radius of shaft bearing journal $R=$ radius of curved rail of test apparatus $T=$ period of oscillation of assembly $g=$ gravitational constant

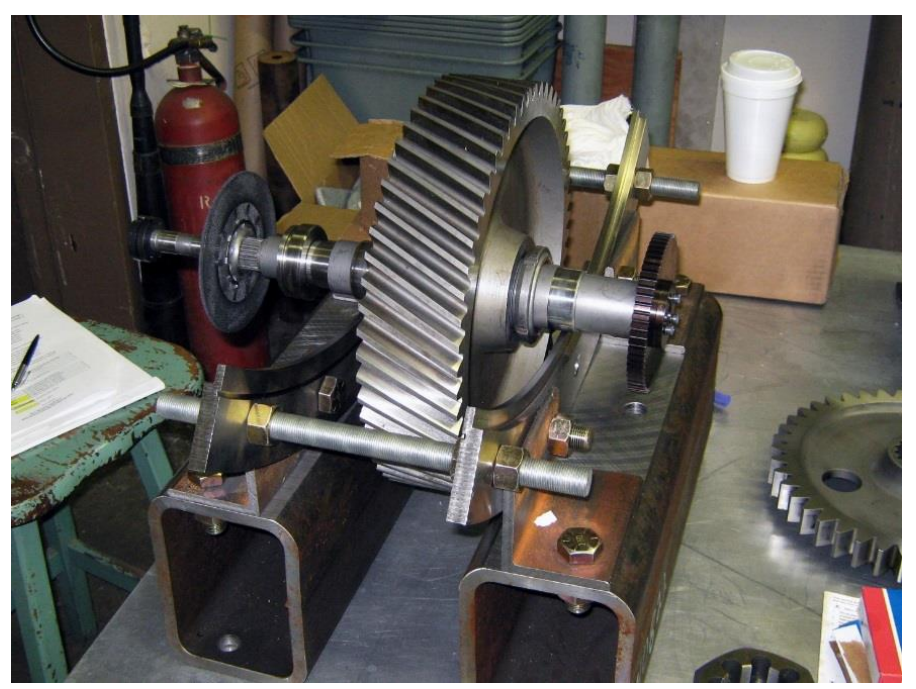

Figure A1 Example experimental set-up for tare loss calculation using curved rail method [A3].

\section{REFERENCES}

[A1] Loewenthal, S. H. "Effect of geometry and operating conditions on spur gear system power loss." Journal of mechanical design 103 (1981): 151

[A2] Dawson, P. H. "Windage loss in larger high-speed gears." Proceedings of the Institution of Mechanical Engineers, Part A: Power and Process Engineering 198.1 (1984): 51-59.

[A3] Genta, Giancarlo, and Cristiana Delprete. "Some considerations on the experimental determination of moments of inertia." Meccanica 29.2 (1994): 125-141. 